INTERNATIONAL JOURNAL OF RESEARCHES IN BIOSCIENCES, AGRICULTURE AND TECHNOLOGY (C) VISHWASHANTI MULTIPURPOSE SOCIETY (Global Peace Multipurpose Society) R. No. MH-659/13(N) www.ijrbat.in

\title{
SYNTHESIS AND CHARACTERIZATION OF COBALT BIS - $\beta$ DIKETONATES
}

\author{
D. S. Panchabhai
}

Anand Niketan College, Warora, M.S., India dhanashripanchbhai@gmail.com

\section{ABSTRACT:}

Bis $-\beta$ diketones have been synthesized by employing Baker Venkantraman Rearrangement on esters (oaroyloxy/heteroaroyloxyacetophenones). The transition metal complexes have been synthesized by simple refluxing the ligand with the transition metal salts. The synthesized compounds were characterized by analytical techniques viz: IR, NMR, Mass and elemental analysis.

Keywords: Bis $-\beta$ diketones, Baker Venkantraman Rearrangement, metal complexes.

\section{INTRODUCTION:}

$\beta$-Diketonates are among the most studied ligands in the chemistry of metal complexes 1-3 The nature of bonding and chelation was elucidated by Werner and Morgan 4-5. $\beta$-diketonates have been exploited as building units in supramolecular 6-15. $\beta$-Diketones have a wide range of used ranging from metal extraction by chelation, to biomedical applications like as antibacterial antibiotics, to being used as a ligand in metal complexes for catalysis ${ }^{16-20}$. The $\beta$-diketonates form a versatile class of chelating ligands ${ }^{21}$ whose uses in transition metal chemistry has been appreciated for almost 120 years $^{22}$. Bis ( $\beta$-diketonate) ligands that form complexes in which both diketonates are bonded to the same metal center have not been previously known. Instead, linked bis ( $\beta$-diketonates) have been used exclusively to construct dimetallic or polymetallic architectures.

$\beta$-Diketone hydrazone derivatives are known to act as good chelating agents.The interest in studying these compounds and their metal complexes arises from their behaviour as efficient antituberculous agents 23 Furthermore, some hydrazones are used as quantitative analytical reagents, especially in colorimetric and fluorimetric determinations of metal ions . Some $\beta$-diketonato complexs of titanium (IV) showed activities against tumors. $\beta$ diketones have a wide range of uses in metal extraction by chelation. 1,3-Diketones are very important compounds in organic chemistry, because they exhibits some biological activities, such as antioxidants, antitumors, and antibacterial activities and are also key intermediates to various heterocyclic compounds $24-25$.Europium (III) $\beta$ diketonates have excellent luminescent property ${ }^{26}$.

\section{Present Work}

The present work describes the preparation 3,3'(4,6-Dihydroxy-1,3-phenyl)bis(1-aryl/heteroaryl propane1,3-diones) and its transition metal complexes. The title compound was synthesized by employing Baker Venkantraman Rearrangement on esters (o-aroyloxy/heteroaroyloxyacetophenones) .The synthesized compounds were characterized by analytical techniques viz: IR, NMR, Mass and elemental analysis.

\section{MATERIAL METHODS:}

A using $(\mathrm{KBr})$ disc on Perkin-Elmer spectrum Rx-I 11 the elemental analyses were done using the Perkin Elmer 2400 CHN analyzer. FT-IR spectra were recorded spectrometer. $\mathrm{H}$ NMR were recorded on Brucker AC-300 F (300 MHz) NMR spectrometer by using DMSO-d and $\mathrm{CDCl}$ as solvent and tetramethylsilane as an internal standard. Mass 
spectra were recorded on 70-S Mass spectrometer using m-nitro benzyl alcohol (NBA) matrix.

\section{4,6- Diacetylresorcinol (resdiacetophenones).} Resorcinol (20.0g, 0.181mole) was dissolves in (42.65g, 0.4178 mole) of acetic anhydride (63.16g, 0.4644 mole) of $\mathrm{ZnCl} 2$ was added and the mixture was heated. After 3 hours of the mixture at $150^{\circ}$ to $160^{\circ} \mathrm{C}, 4,6$-diacetylresorcinol crystallized out. After cooling, $25 \mathrm{~g}$ of water was added for hydrolyzing the remaining acetic anhydride, then $40 \mathrm{~g}$ of methanol was added and, for growing crystals, the resulting mixture was heated under reflux for 30 minutes, then cooled and subjected to solid-liquid separation. The solid was washed with $168 \mathrm{~g}$ of methanol and then dried where by $26.03 \mathrm{~g}(0.1340$ mole) of 46-diacetylresorcinol was obtained. The yield was $73.8 \%$ on the resorcinol basis.

\section{1,3-Dibenzoloxy-4,6-diacetophenone:4,6-}

Diacetylresorcinol (resdiacetophenones) (0.1 mole) and dry pyridine $(10 \mathrm{ml})$, Benzoyl chloride $(0.2 \mathrm{~mole})$ was added slowly maintining the temp. below $20^{\circ} \mathrm{c}$. The reaction mixture was kept overnight and poured on a mixture of ice and $\mathrm{HCl}$. Generally a solid compound separated which was washed with water and dilute $\mathrm{NaOH}$ solution and crystallized from ethanol.The yield is $70 \%$ m.p- $90^{\circ} \mathrm{c}$. .

\section{3,3'-(4,6-dihydroxy-1,3-phenyl) bis (1-phenyl} propane-1,3dione). 1,3-Dibenzoyloxy-4,6diacetophenones $(0.005$ moles) was dissolved in $4 \mathrm{ml}$ of DMSO. To that solution powdered $\mathrm{NaOH}(2 \mathrm{~g})$ was added with vigorous stirring for about five minutes. The stirring was continued for about $5 \mathrm{~min}$ further. The reaction mixture was then cooled and poured on cold water. The pale yellow solid product obtained was washed with water dried and crystallized from alcohol.The yield $67 \%$ and m.p $121^{\circ} \mathrm{C}$
3, aryl/heteroaryl propane1, 3-dionate)] Co(II )(2a). A mixture of $2 \mathrm{~g}\left(5 \times 10^{-3}\right)$ 3,3'-(4,6dihydroxy-1,3- phenyl) bis (1-phenyl propane1,3 dione) and $0.49 \mathrm{~g}\left(2.5 \times 10^{-3}\right)$ cobalt (II)acetate and $50 \mathrm{ml}$ of anhydrous ethanol was stirred at $50-60^{\circ} \mathrm{C}$ for $3 \mathrm{~h}$. The pink solid obtained was washed with ethanol and then with ethyl acetate. The yield was $62.63 \%$. In the same way, all the other cobalt (II) metal complexes $\mathbf{3 b}$-f were prepared by adopting the same procedure.

\section{RESULT \& DISCUSSION :}

1,3-Dibenzoloxy-4,6-diacetophenone

undergoes

Baker-Venkataraman rearrangement to afford pale yellow needles of33,3'-(4,6-dihydroxy-1,3-phenyl) bis (1-phenyl propane-1,3dione)

The structure was further confirmed by the spectral analysis: Ketone group test : It gaves positive test for ketone groupIR (KBr): $3568(-\mathrm{OH})$; higher than that of its metal complexes for most of the3061 (=C$\mathrm{H}) ; 1655$ (-C=O); $1589(\mathrm{C}=\mathrm{C}) ; 29261 \quad(\mathrm{Ar}-\mathrm{H}) ; 1 \mathrm{H}$ bacteria.NMR (DMSO-d6) : 12. 95(s, 1H), 12.72 (s, $1 \mathrm{H}), 3.19(\mathrm{~s}, 1 \mathrm{H}), 8.89(\mathrm{~s}, 1 \mathrm{H}), 8.84(\mathrm{~d}, 2 \mathrm{H}), 7.10-8.17$ $(\mathrm{m}, 12 \mathrm{H}), \mathrm{C}_{24} \mathrm{H}_{18} \mathrm{O}_{6} 7.26(\mathrm{~d}, 1 \mathrm{H}), 6.92(\mathrm{~d}, 1 \mathrm{H}), 7.02$ (s, $1 \mathrm{H})$; MS (EI, 70eV): m/z (\%) 281 ( M+, 100), Anal. Calcd. for C H O : C, 71.60; 1512 4H, 4.46. Found: $\mathrm{C}, 71.12 ; \mathrm{H}, 4.81$. In the $1 \mathrm{H}$ NMR Spectra it gives characteristic peak at 12.95 which)enolic proton and at 12.02 the formation of -diketones. The compound in enolic drugs form is more stable than that of ketonic one.

The complex of synthesized compound $\mathbf{2}$ gives pink coloured Co (II) -diketonate $4 \mathrm{a}$ in high yield. The structure was then confirmed by the spectral analysis

IR (KBr): $3405 \mathrm{~cm}^{-1}(\mathrm{OH})$, ); higher than that of its metal complexes for most of the $1590(\mathrm{C}=\mathrm{C}), 2936$ $(=\mathrm{C}-\mathrm{H}) ;(\mathrm{C}-\mathrm{H}), 1532(-\mathrm{C}=\mathrm{O})$ NMR (DMSO-d6) ) : 11. $95(\mathrm{~s}, \quad 1 \mathrm{H}), \quad 12.72$ (s, $1 \mathrm{H}), \quad 3.19(\mathrm{~s}, \quad 1 \mathrm{H}), 7.10-8.17$ $(\mathrm{m}, 12 \mathrm{H}), .26 \quad(\mathrm{~d}, \quad 1 \mathrm{H}), \quad 6.3 \quad(\mathrm{~d}, \quad 1 \mathrm{H}), \quad$ Anal. 
Calcd. $\mathrm{C}_{48} \mathrm{H}_{40} \mathrm{Co}_{2} \mathrm{O}_{14}$ for $\mathrm{C} \mathrm{H} \mathrm{Co}: \mathrm{C}, 60.13$; H,4.17; Co,15.2 ;Found :C,60.07,H,4.11,Co,10.43 The lowering of $\mathrm{C}=\mathrm{O}$ stretch, metal - oxygen stretch at $484 \mathrm{~cm}^{-1}$ and absence of enolic proton between $814-$ $16 \mathrm{ppm}$ confirms the formation of complex of the ligand 1a with cobalt (II) having molecular formula $\mathrm{C}_{48} \mathrm{H}_{40} \mathrm{Co}_{2} \mathrm{O}_{14}$. Similarly, other transition metal complexes were prepared by the same method. The ligand and its metal8; complexes are quite stable. All the complexes are insoluble in water but soluble in acetone, Methanol and DMSO The complexes are non-electrolytic in nature

\section{CONCLUSION :}

Thus, on the basis of the study results, it is concluded that there is noticeable change in the number of fruits on Cotton, and Tur crops in the study area.

\section{ACKNOWLEDGMENT:}

My sincere thanks are due to the Head, Department of Chemistry, Rashtrasant Tukadoji Maharaj Nagpur University, Nagpur for providing all the necessary laboratory facilities, the Director, SAIF, Punjab University, Chandigarh and VNIT college Nagpur for TGA analysis

\section{REFERANCE :}

Fackler. J. P. (1966): Metal $\quad \beta$-Ketoenolate Complexes, Prog. Inorg. Che, 7:361-425

Lingafelter. E. (1966): Molecular Structure Details Of Metal Chelates Department of Chemistry, University of Waqhington, Coord. Chem. Rev. 1:151-155,

Joshi. K. C, Pathak. V. N. (1977) :Variety in Coordination Modes of Ligands in Metal Complexes .Coord. Chem. Rev. 22, 37.

Schroeder, T., V. Ugrinova, B. Noll and S. Brown ,(2006): A chelating -diketone/phenoxide ligand and its coordination behavior toward titanium and scandium, Dalton Transactions, 1: $1030-1040$

Malhotra, R.C.(1988): Chemistry of metal diketonates, Pure and applied chem., 60: 1349 .

Steinbach. J. F, Burns. J. H.( 1958): Chloroformbearing Chelates. J. Am. Chem. Soc, 80, 18391841 ,
Ueda. T, Eguchi. T, Nakamura. N, Wasylishen. R. E.(2003) : High-Pressure ${ }^{129} \mathrm{Xe}$ NMR Study of Xenon Confined in the Nanochannels of Solid

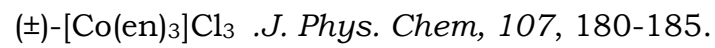

Soldatov. D. V.Ripmeester,(2001): 4-vinylpyndineextended metal-dibenzoylmethanate host frameworks Structure, polymorphism, and inclusion properties. J. A. Chem. Eur. J. 7, 2979-2994.

Soldatov.D.V.Enright,G. D. Ratcliffe. C. I. Henegouwen. A. T, Ripmeester, (2001): Inclusion Potential, Polymorphism, and Molecular Isomerism of Metal Dibenzoylmethanates Coordinated with 2Methylpyridine. J, Chem. Mater, 13, 43224334.

Soldatov.D. V, Enright. G. D, Ripmeester, (2002) :Inclusion Ability of 4-PhenylpyridineExtended Nickel(II) Dibenzoylmethanate, a New Metal-Complex Host $\dagger . J$. A. Chem. Mater. 14, 348-356.

Gromilov. S. A, Baydina. I. A, Zharkova. G. I. (1997): Crystal and molecular structure of trans-bis-(1,1,1-trifluoro-5-methoxy-5-

methyl-2,4-hexanedionato) copper(II) . J. Struct. Chem. 38, 792-798.

Soldatov. D. V, Ripmeester, (2000): Inclusion in Microporous $\quad \beta$-Bis $(1,1,1$-trifluoro-5,5dimethyl-5-

methoxyacetylacetonato)copper(II), an Organic Zeolite Mimic J. A. Chem. Mater. 12, 1827-1839.

Angelova. O, Macicek. J, Atanasov. M, Petrov. G, (1991): Chelating modes of 3-substituted 2,4pentanediones. Crystal and electronic structure of bis(3-cyano-2,4pentanedionato)cobalt(II)Inorg. Chem. 30, 1943-1949.

Caneschi. A, Cornia.A, Fabretti. A. C, Gatteschi. D,(1999) : Structure and Magnetic Properties of a Dodecanuclear Twisted-Ring Iron(III) Cluster. Angew. Chem., Int. Ed. 38, 12951297.

Griesar. K, Haase. W, Svoboda. I, Fuess. H, (1999): Synthesis, Crystal Structure and Magnetic Properties of a Copper(II)-Nitroxide Linear Chain Complex ,Inorg. Chim. Acta, 287, 181185.

Guthrie.J. W, Lintvedt. R. L,Glick. M. D, (1980): Synthesis, magnetic susceptibility, and structure of some binuclear copper(II), nickel(II), and cobalt(II) fluorinated 1,3,5- 
triketonates. Structural and electronic effects on magnetic exchange. Inorg. Chem. 19 , 2949-2956.

Casabo. J, Colomer. J, Escriche. L, Teixidor. F, Molins. E, Miravitlles. C, (1990): An unusual $\beta$-diketone coordination mode. Crystal structure of bis(1,3-bis(2-hydroxyphenyl)-1,3propanedione)tetrakispyridine dimanganese(III). Inorg. Chim. Acta, 178, 221226.

Maverick. A. W, Buckingham. S. C,Yao. Q, Bradbury. J. R, Stanley. Intramolecular coordination of bidentate Lewis bases to a cofacial binuclear copper(II) complex G. G, J. Am. Chem. Soc. 108, 7430- 7431, 1986.

Saalfrank. R. W, Seitz. V. Caulder. D. L, Raymond. K. N, Teichert. M, Stalke. D, Self-Assembly of \{2\}-Metallacryptands and \{2\}-Metallacryptates Eur. J. Inorg. Chem. 1313- 1317, 1998.

Y. Marcus and A.S. Keates, (1969) :Ion exchange and solvent extraction of metal complexes Wiley-Interscience, 499-521.

Bennett, I, J. Broom, R. Cassels, J. Elder, N. Masson and J. Hanlon, 1999. Bioorganic and Medicinal chemistry Lett., 9: 1847-1852
Mehrotra. R. C, Bohra. R, Gaur. D. P, (1978): Metal $\beta$-diketonates and allied derivatives / R.C. Mehrotra, R. Bohra, and D.P. GaurMetal âDiketonates and Allied DeriVatiVes; Academi c Press: New York,.45.

Sacconi. L, (1952): Chemical Reactions of Complexes. I. Action of Hydrazides on Nickel Disalicylaldehyde .J. Am. Chem. Soc, 74:4503

Bennett, I, J. Broom, R. Cassels, J. Elder, N. Masson and J. Hanlon, (1999). Synthesis and antibacterial properties of -diketone acrylate bioisosteres of pseudomonic acid, Bioorganic and Medicinal chemistry Lett., 9: 1847-1852.

Nishiyama, T., S. Shiotsu and H. Tsujita,l 2002). Antioxidative activity and active site of 1,3-indandions with the -diketone moiety, polymer degradation and Stability, 76: 435439.

Sato, K., S. Yamazoe, R. Yamamoto, S. Ohata and A.Ando, (2008). Direct Synthesis of 1,3Diketones by Rh-Catalyzed Reductive rAcylation of Enones, Organicletters, 10: 24052408.

\section{Elemental Analysis of 3,3'-(4,6-Dihydroxy-1,3-phenyl)bis [(1-aryl/heteroaryl propane1,3-dionate)] Co (II) 2a-f}

\begin{tabular}{|c|c|c|c|c|c|c|c|c|c|}
\hline \multirow{2}{*}{$\begin{array}{l}\text { Com- } \\
\text { pound }\end{array}$} & \multirow{2}{*}{$\begin{array}{l}\text { Colour } \\
\text { with } \\
\mathrm{FeCl}_{3} \\
\text { Red }\end{array}$} & Ar-Aryl & $\begin{array}{l}\text { Emprical } \\
\text { formula }\end{array}$ & Yield & \multicolumn{2}{|c|}{ Calc.(found) } & & $\begin{array}{l}\% \mathrm{M} \\
\text { Calc. } \\
\text { (found) }\end{array}$ & \multirow[t]{2}{*}{$\begin{array}{l}\text { Decom- } \\
\text { position } \\
\text { Temp. }{ }^{\circ} \mathrm{C}\end{array}$} \\
\hline & & $\mathrm{C}_{6} \mathrm{H}_{5}$ & $\mathrm{C}_{48} \mathrm{H}_{40} \mathrm{Co}_{2} \mathrm{O}_{14}$ & 62.63 & $\begin{array}{l}60.13 \\
(60.07)\end{array}$ & $\begin{array}{l}4.17 \\
(4.11)\end{array}$ & - & $\begin{array}{l}15.2 \\
(10.43)\end{array}$ & \\
\hline $\mathbf{2 b}$ & Brown & $4-\mathrm{OCH}_{3} \mathrm{C}_{6} \mathrm{H}_{5}$ & $\mathrm{C}_{52} \mathrm{H}_{48} \mathrm{Co}_{2} \mathrm{O}_{18}$ & 64.94 & $\begin{array}{l}57.89 \\
(57.85)\end{array}$ & $\begin{array}{l}4.45 \\
(4.40)\end{array}$ & - & $\begin{array}{l}10.75 \\
(9.58)\end{array}$ & 420 \\
\hline $2 c$ & Red & $4-\mathrm{ClC}_{6} \mathrm{H}_{4}$ & $\mathrm{C}_{48} \mathrm{H}_{36} \mathrm{Co}_{2} \mathrm{O}_{14} \mathrm{Cl}_{4}$ & 63.90 & $\begin{array}{l}52.64 \\
(52.60)\end{array}$ & $\begin{array}{l}3.28 \\
(3.25)\end{array}$ & - & $\begin{array}{l}9.97 \\
(7.21)\end{array}$ & 430 \\
\hline $2 d$ & Brown & $4-\mathrm{CH}_{3} \mathrm{C}_{6} \mathrm{H}_{4}$ & $\mathrm{C}_{52} \mathrm{H}_{48} \mathrm{Co}_{2} \mathrm{O}_{14}$ & 69.10 & $\begin{array}{l}61.56 \\
(61.52)\end{array}$ & $\begin{array}{l}4.73 \\
(4.69)\end{array}$ & - & $\begin{array}{l}10.95 \\
(10.10)\end{array}$ & 450 \\
\hline $2 e$ & Red & & $\mathrm{C}_{40} \mathrm{H}_{32} \mathrm{Co}_{2} \mathrm{O}_{14} \mathrm{~S}_{2}$ & 65.43 & $\begin{array}{l}52.34 \\
(52.30)\end{array}$ & $\begin{array}{l}3.48 \\
(3.42)\end{array}$ & - & $\begin{array}{l}10.39 \\
(10.2)\end{array}$ & 430 \\
\hline $2 f$ & Red & & $\mathrm{C}_{44} \mathrm{H}_{32} \mathrm{Co}_{2} \mathrm{O}_{14} \mathrm{~N}_{2}$ & 63.22 & $\begin{array}{l}55.63 \\
(55.60)\end{array}$ & $\begin{array}{l}3.37 \\
(3.33)\end{array}$ & $\begin{array}{l}5.05 \\
(5.00)\end{array}$ & $\begin{array}{l}12.02 \\
(11.62)\end{array}$ & 480 \\
\hline
\end{tabular}

Scheme: Synthesis of ligand and its metal complexes. 
1. 1,3-Diaroyloxy/heteroaroyloxy-4,6-diacetophenones 2<smiles>CC(=O)c1ccc(O)c(C(C)=O)c1</smiles>

2. 3',3-(4,6-dihydroxy-1,3-phenyl) bis (1-aryl/heteroaryl propane-1,3diones)<smiles>CC(=O)c1cc(C(C)=O)c(OC(=O)[Ge])cc1OC(=O)[Al]</smiles>

$\mathrm{Ar}=\mathrm{Ar}_{1}$

(a) $\mathrm{C}_{6} \mathrm{H}_{5} \quad \mathrm{Ar}$

$=\mathrm{Ar}_{1}$

(b) $4-\mathrm{CH}_{3} \mathrm{C}_{6} \mathrm{H}_{4}$

(c) 4-

$\mathrm{OCH}_{3} \mathrm{C}_{6} \mathrm{H}_{4}$

(f)

(d) $4-\mathrm{ClC}_{6} \mathrm{H}_{4}$

3.

(e) $\langle\sqrt{\mathrm{a}}$

)

${ }_{N}$

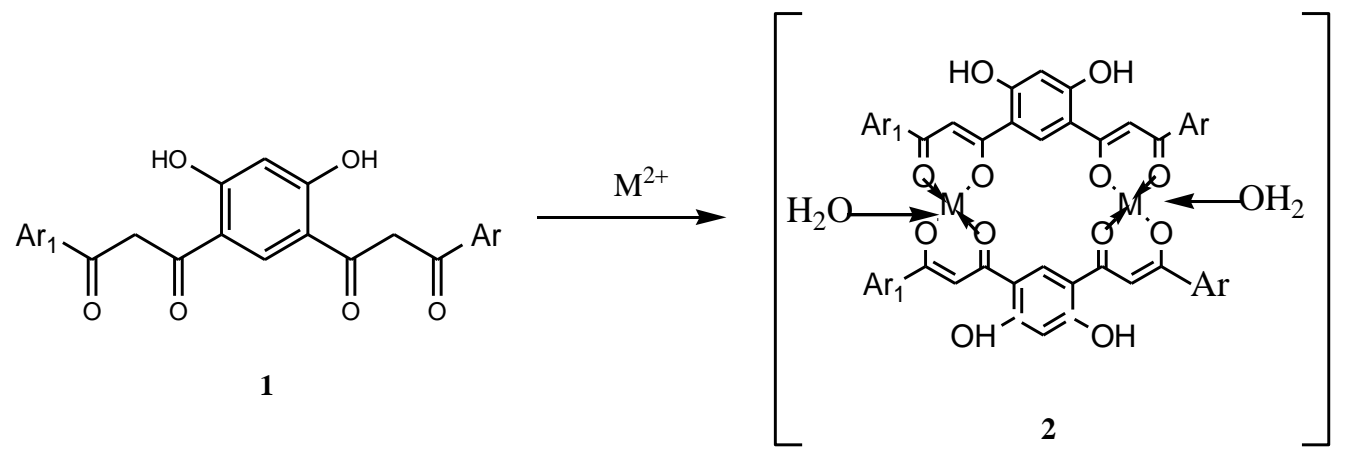

$\mathrm{M}=\mathrm{Co}(\mathrm{II})$ 